\title{
LANGUAGE LEARNING BELIEFS AND STRATEGIES: A BOSNIAN EFL CASE
}

\author{
Ervin Kovačević \\ International Univeristy of Sarajevo, Bosnia and Herzegovina \\ Azamat Akbarov \\ International Burch University, Bosnia and Herzegovina
}

\begin{abstract}
Correlation studies (Li, 2010; Chang \& Shen, 2010) between the clusters of survey items as originally suggested for The Beliefs About Language Learning Inventory BALLI (EFL version; Horwitz, 1988) and Strategy Inventory for Language Learning - SILL 7.0 (Oxford, 1990) report generally weak and moderate positive correlation coefficients. The above survey instruments were administered to fifty freshman students of Bosnian linguistic and cultural background at International University of Sarajevo. Correlation tests partly confirmed results reported by Li (2010) and Chang and Shen (2010) but with more similar correlation coefficients with respect to the later authors. The results partly reflect universal features of the foreign language learner and indicate that the theory of reciprocity between the two research constructs should be focused on findings about other forms of human intelligence.
\end{abstract}

Keywords: Language; Learning; Beliefs; Strategies; BALLI; SILL; Correlation. 


\section{Introduction}

Learner-centered educational models assume that every learner is unique. Assuming that learners' personal perceptions define their goals, a learner-centered teacher always attempts to match the content and manner of presenting it with the learner and her/his needs (Zmuda, Curtis, \& Ullman, 2015; Conti, 2004). Accordingly, it is assumed that the study of learners' beliefs about language learning and language learning strategies will contribute to better understanding of the learner and improve the practices driven by learner-centered education frameworks.

Language learner strategies associated with cognitive, metacognitive, and affective components are believed to underlie language learners' behaviors and beliefs. These strategies argue the provision of crucial information about learner behavior and beliefs as necessary for a successful foreign or second language teaching design (Horwitz, 2013, 1988; Oxford, 2013, 1990; Wenden, 1998, 1991). The need for such information is supported by positive correlations between language learning beliefs and strategies (Chang \& Shen, 2010; Li, 2010).

Hence this study explores the relationship between the beliefs and strategies as reported by university students of Bosnian linguistic and cultural background. The results partly confirm previous research findings and also provide important implications for further research.

\section{Literature Review}

It is not surprising that defining and studying the phenomenon of beliefs about learning is both challenging and diverse. The verb 'to believe'-classified as a stative verb of cognition, emotion, and sensation-is used to express a mental state or attitude towards somebody or something (Huddleston \& Pullum, 2002). In other words, the concept of belief is semantically complicated. In addition, the act of learning as expressed in various educational frameworks may also be defined in numerous ways. Consequently, the notion of learning belief is difficult to define in the narrow sense and must be defined with reference to overlapping or similar notions.

Barcelos (2000) examines the relationship existing between 'beliefs' and 'knowledge' and 'beliefs' and 'actions'. Relying on Dewey (1906/1983), Hickman (1998) and Boisvert (1998), she concludes that while "beliefs may present obstacles for reflective inquiry, [...] they may also trigger reflection” (Barcelos, 2000, p. 36), because beliefs and knowledge seem to correlate with the link between subjective 
experience and inquiry. In linking beliefs with actions, Barcelos (2000) argues that the relationship is reciprocal.

Wenden (1998) associates 'beliefs and knowledge about learning' with the term "metacognitive knowledge" (p. 515). Inspired by Flavell (1979), Wenden (1998) explains that metacognitive knowledge can be classified as 'person knowledge', 'task knowledge' and 'strategic knowledge'. Relying on Wenden's classification, it could be argued further that learning beliefs stand for learners' general beliefs about learning processes, specific beliefs about themselves as learners, beliefs about the nature of a learned subject and beliefs about the ways of mastering the learning process.

Horwitz (1988) put forward a very strong argument when she said "If beliefs about language learning are prevalent in the culture at-large, then foreign language teachers must consider that students bring these beliefs with them into the classroom" (p. 283). In support of this argument, she draws on the results of a survey that included eighty students of German, sixty-three students of French, and ninety-eight students of Spanish. All students were in first semester language courses at the University of Texas (Horwitz, 1988). Horwitz's (1988) survey was designed "to assess student opinions on a variety of issues and controversies related to language learning" (p. 284). The instrument she designed is The Beliefs About Language Learning Inventory - BALLI. It is used by dozens of researchers across the world and has become "[t]he most widely used questionnaire" (Barcelos, 2000, p. 45) for research about beliefs in language learning. The study has also revealed that learners hold variegated beliefs about language learning.

Horwitz (2013) later remarked that the BALLI "is not a single scale so the items should not be added together or averaged” (p. 261). However, earlier BALLI studies assessed students' beliefs "in five major areas: 1) difficulty of language learning; 2) foreign language aptitude; 3 ) the nature of language learning; 4) learning and communication strategies; and 5) motivations and expectations" (Horwitz, 1988, p. 284). It should be noted that Nikitina and Furuoka (2006) statistically supported Horwitz's choice of belief areas.

While the link between beliefs about language learning and foreign language producing behaviors may seem a little vague, research has pointed out that the link can be shaped by several complex mechanisms such as reflective practice and metacognition. One set of the agents assumed to play a very important role in this link was studied under the name of language learning strategies. Language learning strategies were found "to deal with the receptive domain of intake, memory, storage, and recall” (Brown, 2000, p. 127). This finding may indicate their existence in both 
forms of action and thought.

According to Weinstein and Mayer (1983) learning strategies are "behaviors and thoughts in which a learner engages and which are intended to influence the learner's encoding process" (p. 3). Oxford (1990) explains that learning strategies are commonly defined as "operations employed by the learner to aid the acquisition, storage, retrieval, and use of information" (p. 8). Oxford (1990) found that this definition does not fully reveal the concept of learning strategy and suggests that it would be useful to extend the definition by referring to learning strategies as "specific actions taken by the learner to make learning easier, faster, more enjoyable, more selfdirected, more effective, and more transferrable to new situations" (p. 8).

Learning strategies have also been studied under different names namely, "learning skills, learning-to-learn skills, thinking skills, and problem solving skills" (Oxford, 1990, p. 2). Thus hypotheses, theories, and empirical findings which attempt to unveil the role of cognitive processes lie at the core of learning strategy research. For example, Sternberg's triarchic theory of human intelligence (1985) is a very important reference point, if it is assumed that learning strategies manifest as actions, operations, or decisions that shape learning behaviors. Sternberg's theoretical model describes how human intelligence functions; how mechanisms of learning, planning, monitoring, problem solving, decision making and implementing interrelate (Sternberg \& Sternberg, 2012). In this sense it provides theoretical ground for interpreting the concept of learning strategies as deliberate self-employed acts with the aim to shape both learning processes and outcomes.

Wenden (1991) implied that two of the three factors that regulate the use of learning strategies are learner profile related. She states that learners' "background knowledge about subject matter content, [...] about learning the nature of the materials to be learned and the product or outcome that the learner or teacher has in mind" (p. 31) shape the use of strategies. The corollary is that this type of reasoning identifies learning strategies as key mechanisms in 'autonomous or self-regulated learning' models. In the Strategic Self-Regulation ( $\left.\mathrm{S}^{2} \mathrm{R}\right)$ model of language learning, the learning strategies are defined as "deliberate, goal-directed attempts to manage and control efforts to learn the L2 (based on Afflerbach, Pearson, and Paris, 2008)" (Oxford, 2013, p.12).

Rubin (1975) initially defined learning strategies as "the techniques or devices which a learner may use to acquire knowledge" (p. 43). The author later offered a binary classification (Rubin, 1981): 'the direct learning strategies' and 'the indirect learning strategies' (Griffiths, 2004). Hsiao and Oxford (2002) report that 
Rubin's (1981) dichotomy "along with the non-L2 work of Dansereau (1985) and others, led to Oxford's (1990) direct and indirect L2 learning strategies” (p. 370). Oxford's (1990) taxonomy of language learning strategies classifies the strategies across six categories: memory, cognitive, metacognitive, compensation, social, and affective. It is argued that O'Malley and Chamot's (1990), Rubin's (1981) and Oxford's (1990) classifications "have made an important contribution to and have advanced our understanding of how strategies can be systematically categorized" (Hsiao \& Oxford, 2002, p.377).

Barcelos (2000) claims that beliefs about language learning and language learning strategies are correlated (see Abraham \& Vann, 1987; Elbaum, Berg, \& Dodd, 1993; Riley, 1997; Yang, 1992; as cited in Barcelos, 2000). Calling on Riley (1997) and Abraham and Vann (1987), Barcelos (2000) explains that beliefs influence actions through strategy preferences which serve as links between the two. In addition, she reminds us of the arguments advanced by Yang (1992), Murphey (1996), and Riley (1997), which implied that beliefs are influenced by strategies/ actions (Barcelos, 2000).

Chang and Shen (2010) surveyed three hundred and seventeen students in two Taiwanese high schools. The authors wanted to explore the relationship between the beliefs about language learning and language learning strategies. They administered BALLI to identify the beliefs held and the SILL, Strategy Inventory for Language Learning developed by Oxford (1990) to identify what strategies were relied on. The strongest coefficients they found are stated as follows:

Based on the result of Pearson correlation, the current study displays a moderate association $(\mathrm{r}=0.444, \mathrm{p}=.000)$ between participants' beliefs about language learning and their use of learning strategies. When each subcategory of the BALLI and the SILL, was examined the result of Pearson correlation also indicated a significant linkage in each subcategory of the BALLI and the SILL. Among these significant correlations, the first subcategory in the BALLI, "Foreign Language Aptitude", had the strongest relationship with compensation strategy $(\mathrm{r}=.231, \mathrm{p}=.000)$. The second subcategory in the BALLI, "Difficulty of Language Learning", had the highest correlation with memory $(\mathrm{r}=$ $.427, \mathrm{p}=.000)$, cognitive and affective strategy $(\mathrm{r}=.387, \mathrm{p}$ $=.000)$. The last subcategory in the BALLI, motivation, had the most notable correlation with overall $\operatorname{SILL}(\mathrm{r}=0.422, \mathrm{p}$ 
$=.000)$ and three SILL subcategories: cognitive strategy $(\mathrm{r}$ $=.387, \mathrm{p}=.000)$, metacognitive $(\mathrm{r}=.455, \mathrm{p}=.000)$, social strategies $(\mathrm{r}=.340, \mathrm{p}=.000)$. (Chang \& Shen, 2010, p. 6)

$\mathrm{Li}(2010)$ administered the SILLand 'Language Learning Belief Questionnaire' (see Lu, 2003; as cited in Li, 2010), which is partly composed of the BALLI items, to two hundred and fourteen second-year English majors from four vocational and technology colleges in China. Li (2010) attempted to diagnose the subjects' beliefs about language learning and language learning strategies. She also tried to diagnose the correlation between the beliefs and strategies using the Pearson test as presented in Table 1 below:

Table 1: Correlation between language learning beliefs and strategies in Li (2010, p. 862)

\begin{tabular}{|c|c|c|c|c|c|c|c|}
\hline & & Memory & Cognitive & Compensation & $\begin{array}{l}\text { Meta- } \\
\text { cognitive }\end{array}$ & Affective & Social \\
\hline \multirow{2}{*}{$\begin{array}{l}\text { Language } \\
\text { Aptitude }\end{array}$} & $\mathrm{r}$ & .133 & $.271^{* * *}$ & $.180^{* * *}$ & $.223^{* *}$ & .126 & $.227^{* * *}$ \\
\hline & sig & .052 & .000 & .008 & .001 & .066 & .001 \\
\hline \multirow{2}{*}{$\begin{array}{l}\text { Difficulty of } \\
\text { Language } \\
\text { Learning }\end{array}$} & r & .125 & $.226 * *$ & .052 & $.171^{*}$ & $.153^{*}$ & .129 \\
\hline & sig & .068 & .001 & .448 & .012 & .025 & .059 \\
\hline \multirow{2}{*}{$\begin{array}{l}\text { Nature of } \\
\text { Language } \\
\text { Learning }\end{array}$} & $\mathrm{r}$ & .040 & .066 & .069 & $.171^{*}$ & $.169 *$ & $.139 *$ \\
\hline & sig & .564 & .336 & .312 & .012 & .014 & .042 \\
\hline \multirow{2}{*}{$\begin{array}{l}\text { Learning and } \\
\text { Communication } \\
\text { Strategies }\end{array}$} & $\mathrm{r}$ & $.165^{*}$ & $.285^{* * *}$ & $.302^{* * *}$ & $.306^{* *}$ & $.368 * *$ & $.319 * *$ \\
\hline & sig & .016 & .000 & .000 & .000 & .000 & .000 \\
\hline \multirow{2}{*}{$\begin{array}{l}\text { Motivation and } \\
\text { Expectations }\end{array}$} & $\mathrm{r}$ & $.159 *$ & .129 & .083 & $.224^{* * *}$ & $.156^{*}$ & $.170 *$ \\
\hline & sig & .020 & .059 & .228 & .001 & .022 & .013 \\
\hline \multirow{2}{*}{$\begin{array}{l}\text { Mother-tongue } \\
\text { Reliance }\end{array}$} & $\mathrm{r}$ & -.098 & $-.163 *$ & .008 & -.059 & -.047 & -.100 \\
\hline & sig & .154 & .017 & .912 & .390 & .495 & .144 \\
\hline
\end{tabular}

* Correlation is significant at the 0.05 level (2-tailed)

${ }^{*}$ Correlation is significant at the 0.01 level (2-tailed)

$\mathrm{Li}$ (2010) concludes that the "results were primarily in line with other studies (Horwitz, 1987, 1988; Wenden, 1987; Abraham \&Vann; 1987, Yang, 1992; Wen \& Johnson, 1997)" (p. 864).

Saeb and Zamani (2013) surveyed two hundred and sixty-two Iranian highschool students administering the BALLI and the SILL. The questions they tried to answer were whether "high-school students differ in their use of language learning 
strategies from students [who are at the same time] attending English institutes" and whether "high-school students' beliefs about language learning [are] different from those of students attending English institutes" (Saeb \& Zamani, 2013, p. 81). They found a statistically significant difference between the two groups namely:

There was a statistically significant difference between highschool students and students attending English institutes regarding their use of language learning strategies, $\mathrm{F}(6,257)$ $=7.25, \mathrm{P}=.000$; Wilks' Lambda $=.85$; partial eta squared $=.14 \ldots$ The MANOVA results revealed a statistically significant difference between high-school students and students attending English institutes in terms of their beliefs about language learning, $\mathrm{F}(5,256)=7.02, \mathrm{P}=.000$; Wilks' Lambda $=.87$; partial eta squared $=.12$. (Saeb \& Zamani, 2013, pp. 82-83)

When the results provided by Chang and Shen (2010) and Li (2010) are compared some slight differences appear (see Table 2).

Table 2: Comparison of strongest correlation results between language learning strategies and beliefs about language learning obtained by Chang and Shen (2010) and Li (2010)

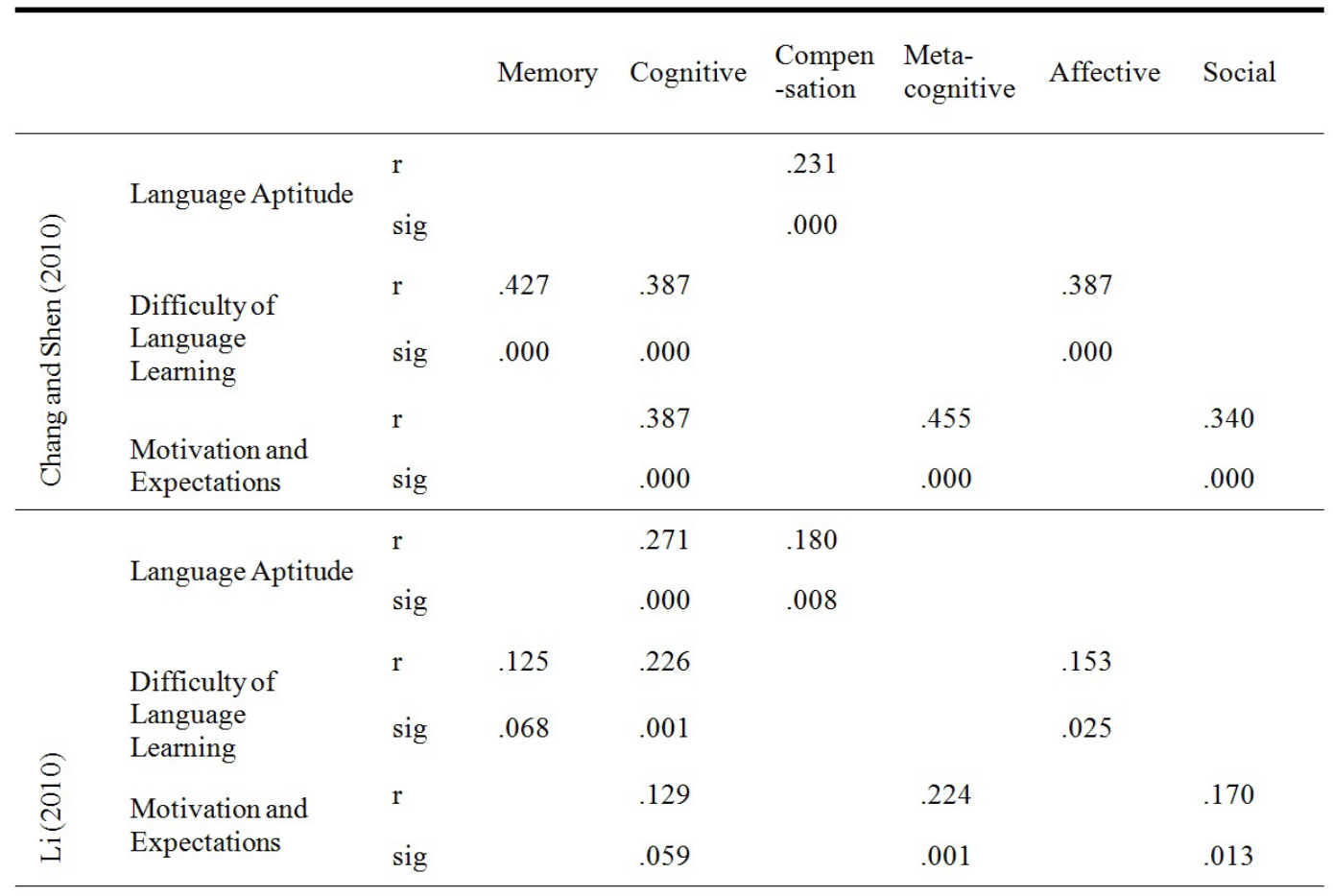


As it can be observed the significance of statistical results and correlation coefficients vary. The biggest differences were found to be between the metacognitive strategies and motivation, the affective strategies and difficulty of language learning, and the social strategies and motivation. Overall, Chang and Shen (2010) report stronger correlation coefficients. It might be speculated that the contextual factors were the reason for the different results. Chang and Shen (2010) conducted the survey with Taiwanese high school students, while Li (2010) surveyed Chinese college students. Saeb and Zamani (2013) statistically confirmed that educational settings and learning experience affect both learning strategy choices and beliefs about language learning held by participants. The correlations, however, between these two concepts need to be further clarified and statistically tested. This research project will attempt to provide further insights about the strength of correlation between beliefs about language learning and language learning strategies.

\section{Instruments, Participants and Data Analysis}

Two instruments were used in this study: The Beliefs about Language Learning Inventory-BALLI (Horwitz, 1988) and the Strategy Inventory for Language LearningSILL 7.0 (Oxford, 1990). Fifty subjects participated in the study: twenty-one females and twenty-nine males. All participants were of Bosnian cultural and linguistic background, proficient in English (as measured by the Institutional Proficiency Test) and enrolled in the freshman year at International University of Sarajevo. The data was collected on several occasions during the Spring Semester 2015 using original instruments after the authors' consents were obtained. The data was analyzed using the SPSS software. Since the number of participants was not very high (due to the nature of the educational setting), the quality of the research sample was examined using the Shapiro-Wilk test, visual inspection of their histograms, normal Q-Q plots and box plots, and Pearson and Spearman tests.

\section{Results}

The Shapiro-Wilk's test $(\mathrm{p}>.05)$, visual inspection of their histograms, normal Q-Q plots and box plots showed that the language learning strategy scores approximated a normal distribution for both females and males in all the clusters of scores except the scores of affective and social strategies as declared by males.

The above mentioned tests showed that the language learning beliefs scores approximated a normal distribution for both females and males in clusters of beliefs about the difficulty of language learning, the nature of language learning and motivation and expectations. However, the scores for foreign language aptitude as declared by females were found to be kurtotic. Learning and communication 
strategies as declared by females were found not to be normally distributed by the Shapiro-Wilk's test $(\mathrm{p}=0.01)$. Finally, Pearson and Spearman tests provided following results in Table 3.

Table 3: Correlations between Beliefs about Language Learning and Language Learning Strategies

\begin{tabular}{|c|c|c|c|c|c|c|}
\hline & Memory & Cognitive & Compensation & Metacognitive & Affective & Social \\
\hline \multirow{2}{*}{$\begin{array}{l}\text { Language } \\
\text { Aptitude }\end{array}$} & $\mathrm{r}_{\mathrm{s}}=.259$ & $\mathrm{r}_{\mathrm{s}}=.180$ & $\mathrm{r}_{\mathrm{s}}=.030$ & $\mathrm{r}_{\mathrm{s}}=.316^{*}$ & $\mathrm{r}_{\mathrm{s}}=.193$ & $\mathrm{r}_{\mathrm{s}}=.093$ \\
\hline & $\mathrm{p}=.069$ & $\mathrm{p}=.211$ & $\mathrm{p}=.835$ & $\mathrm{p}=.025$ & $\mathrm{p}=.180$ & $\mathrm{p}=.521$ \\
\hline \multirow{2}{*}{$\begin{array}{l}\text { Difficulty of } \\
\text { Language } \\
\text { Learning }\end{array}$} & $\mathrm{r}=-.008$ & $\mathrm{r}=.142$ & $\mathrm{r}=-.015$ & $r=-.046$ & $\mathrm{r}_{\mathrm{s}}=.105$ & $\mathrm{r}_{\mathrm{s}}=-.120$ \\
\hline & $\mathrm{p}=.959$ & $\mathrm{p}=.325$ & $\mathrm{p}=.918$ & $\mathrm{p}=.753$ & $\mathrm{p}=.468$ & $\mathrm{p}=.406$ \\
\hline \multirow{2}{*}{$\begin{array}{l}\text { Nature of } \\
\text { Language } \\
\text { Learning }\end{array}$} & $\mathrm{r}=.205$ & $\mathrm{r}=.206$ & $r=-.017$ & $\mathrm{r}=.366^{* *}$ & $\mathrm{r}_{\mathrm{s}}=.219$ & $\mathrm{r}_{\mathrm{s}}=.369 * *$ \\
\hline & $\mathrm{p}=.154$ & $\mathrm{p}=.151$ & $\mathrm{p}=.909$ & $\mathrm{p}=.009$ & $\mathrm{p}=.126$ & $\mathrm{p}=.008$ \\
\hline \multirow{2}{*}{$\begin{array}{l}\text { Learning and } \\
\text { Communicatio } \\
\text { n Strategies }\end{array}$} & $\mathrm{r}_{\mathrm{s}}=.291 *$ & $\mathrm{r}_{\mathrm{s}}=.454 * *$ & $\mathrm{r}_{\mathrm{s}}=0.248$ & $\mathrm{r}_{\mathrm{s}}=.477 * *$ & $\mathrm{r}_{\mathrm{s}}=.496 * *$ & $\mathrm{r}_{\mathrm{s}}=.292 *$ \\
\hline & $\mathrm{p}=.040$ & $\mathrm{p}=.001$ & $\mathrm{p}=.083$ & $\mathrm{p}=.000$ & $\mathrm{p}=.000$ & $p=.040$ \\
\hline \multirow{2}{*}{$\begin{array}{l}\text { Motivation and } \\
\text { Expectation }\end{array}$} & $\mathrm{r}=.286^{*}$ & $\mathrm{r}=.347 *$ & $\mathrm{r}=.262$ & $\mathrm{r}=.343^{*}$ & $\mathrm{r}_{\mathrm{s}}=.442 * *$ & $\mathrm{r}_{\mathrm{s}}=.324 *$ \\
\hline & $\mathrm{p}=.044$ & $\mathrm{p}=.013$ & $\mathrm{p}=.066$ & $\mathrm{p}=.015$ & $\mathrm{p}=.001$ & $\mathrm{p}=.022$ \\
\hline
\end{tabular}

* Correlation is significant at the 0.05 level (2-tailed)

** Correlation is significant at the 0.01 level (2-tailed)

\section{Discussion}

The results obtained through this study seem to be similar to those obtained by Chang and Shen (2010) in comparison to the results provided by $\mathrm{Li}$ (2010) (see Table 4). Particularly interesting here is the consistency of the correlation coefficients between beliefs about 'motivation and expectations' and all six categories of language learning strategies in all three studies.

Chang and Shen (2010) did not provide all the correlation coefficients in their report. In addition, some of the coefficients provided by $\mathrm{Li}$ (2010) and this current research were found not to be statistically significant. It is difficult, therefore, to make accurate comparisons of the correlation coefficients. However, almost all the coefficients indicate weak and moderate positive correlations between beliefs about language learning and language learning strategies as classified by Horwitz (1988) and Oxford (1990). The implications of this finding are nevertheless far-reaching if the variance they share is calculated. 
Table 4: Comparison of correlation results between language learning strategies and beliefs about language learning obtained by Chang and Shen (2010), Li (2010, and authors of this research

\begin{tabular}{|c|c|c|c|c|c|c|c|c|}
\hline & & & Memory & $\begin{array}{l}\text { Cogni- } \\
\text { tive }\end{array}$ & $\begin{array}{l}\text { Compen- } \\
\text { sation }\end{array}$ & $\begin{array}{l}\text { Meta- } \\
\text { cognitive }\end{array}$ & Affective & Social \\
\hline \multirow{4}{*}{ 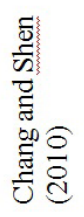 } & \multirow{2}{*}{$\begin{array}{l}\text { Language } \\
\text { Aptitude }\end{array}$} & $\mathrm{r}$ & & & .231 & & & \\
\hline & & sig & & & .000 & & & \\
\hline & \multirow{2}{*}{$\begin{array}{l}\text { Motivation } \\
\text { and } \\
\text { Expectations }\end{array}$} & $\mathrm{r}$ & & .387 & & .455 & & .340 \\
\hline & & sig & & .000 & & .000 & & .000 \\
\hline \multirow{6}{*}{$\begin{array}{l}\stackrel{0}{\circ} \\
\stackrel{d}{3}\end{array}$} & \multirow{2}{*}{$\begin{array}{l}\text { Language } \\
\text { Aptitude }\end{array}$} & $\mathrm{r}$ & .133 & & & & & \\
\hline & & sig & .052 & & & & & \\
\hline & \multirow{2}{*}{$\begin{array}{l}\text { Nature of } \\
\text { Language } \\
\text { Learning }\end{array}$} & $\mathrm{r}$ & & & & .171 & & .139 \\
\hline & & sig & & & & .012 & & .042 \\
\hline & \multirow{2}{*}{$\begin{array}{l}\text { Motivation } \\
\text { and } \\
\text { Expectations }\end{array}$} & $\mathrm{r}$ & & .129 & .083 & .224 & .156 & .170 \\
\hline & & sig & & .059 & .228 & .001 & .022 & .013 \\
\hline \multirow{6}{*}{ 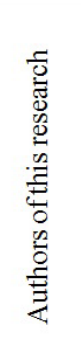 } & \multirow{2}{*}{$\begin{array}{l}\text { Language } \\
\text { Aptitude }\end{array}$} & $\mathrm{r}$ & $\mathrm{r}_{\mathrm{s}}=.259$ & & & $\mathrm{r}_{\mathrm{s}}=.316$ & & \\
\hline & & sig & .069 & & & .025 & & \\
\hline & $\begin{array}{l}\text { Nature of } \\
\text { Language }\end{array}$ & $\mathrm{r}$ & & & & .366 & & $\mathrm{r}_{\mathrm{s}}=.369$ \\
\hline & Learning & sig & & & & .009 & & .008 \\
\hline & $\begin{array}{l}\text { Motivation } \\
\text { and }\end{array}$ & $\mathrm{r}$ & .286 & .347 & .262 & .343 & $\mathrm{r}_{\mathrm{s}}=.442$ & $\mathrm{r}_{\mathrm{s}}=.324$ \\
\hline & Expectations & sig & .044 & .013 & .066 & .015 & .001 & .022 \\
\hline
\end{tabular}

If the correlation coefficients are squared $\left(\mathrm{r}^{2}\right)$, the shared variance oscillates approximately between 4 and $20 \%$. In other words, approximately 4 to $20 \%$ of language learning strategy choice can be accounted for by beliefs about language learning held, and vice versa (Dancey \& Reidy, 2011; 1999). The 20\% resulted from a few strong coefficients identified (e.g. correlation between beliefs about motivation and expectations and metacognitive strategies was found to be positive $(\mathrm{r}=.455, \mathrm{p}=$ .000 , see Chang and Shen, [2010]) - so $20.7 \%$ of the variance between them could be found to account for each other $\left(r^{2}=0.207\right)$. However, other obtained coefficients appear to be lower. These statistics highlight the complexity of both the phenomena of beliefs and strategies.

As attitudes do, beliefs also project an individual's interaction between cognition and emotion, which shapes the levels of both conviction and doubt about ways, persons, things, or concepts. Consequently, attitudes and beliefs are difficult to distinguish because they both may be described as predispositions to actions, and they both may be incompatible with the actions. Describing the difference between the terms, Barcelos (2000) refers to Rokeach (1968) who "explained the difference 
between the two terms by stating that beliefs are predispositions to action, whereas an attitude is a set of interrelated predispositions to action organized around an object or situation" (p. 7). The distinction has also been implied by George and Jones (1997) who defined 'values' as "person's beliefs about what is good or desirable in life" which operate as "long-term guides for a person's choices and experiences" (as cited in Arnold et al. p. 242). What these definitions suggest is that attitudes project beliefs, and beliefs, together with feelings, compose attitudes.

While discussing language-learning strategies and their associations with good and bad learners, Gass and Selinker (2001) conclude that research on this paradigm is still preliminary and that "a next obvious step in the evolution of the research paradigm would be the undertaking of longitudinal studies that attempt to link learning strategies, which are thought to be helpful to an individual, to the interlanguage output these individuals produce (p. 369). Gu (2010) found that "the intensity of interest in language learning strategies in the 1980s and the 1990s and the high expectations from theorists, researchers, teachers, and learners have left many people frustrated, especially because of the conceptual fuzziness and elusiveness of the LLS [language learning strategies] construct" (as cited in Oxford, 2013, p. 10). The author suggests that new researchers create "innovative research paths" and avoid answering "old research questions" (Gu, 2010; as cited in Oxford, 2013, p. 10).

\section{Conclusion}

Although language learning beliefs and strategies are generally positively correlated, the results indicate that the overall relationship between them is not strong. Therefore, any theorizing about their reciprocity should include other findings about theories of human intelligence. For example, the interacting processes between the learners' personal and situational characteristics, the learners' choosing between reflecting or non-reflecting on the interacting processes, and the ongoing interrelations between personal skills, knowledge and attitudes. Together these factors might or might not be contextually restrained. Such a connection has been addressed by several scholars (Mezirow, 1991; Jarvis, 2003; 1987; Cross, 1981; McClusky, 1963; Knox, 1986; and Knowles, 1990). The relatively low shared variances between language learning beliefs and strategies, which are not frequently highlighted in similar studies, should not be disregarded.

The results reported in this research correspond more closely with Chang and Shen (2010) than those of Li (2010). Indeed Chang and Shen and Li's research projects are very similar to the current research. The similarity of results partly highlights universal beliefs and values of the foreign language learner, which is 
sometimes overlooked by learner-centered educational practices. In addition, it implies that instructors' success in deliberate modification of either learners' beliefs or strategies will also depend on other contextual factors. Therefore acting on one mechanism to change the other might not be enough. The learner displays behaviors, takes actions, and makes decisions in order to learn. Types of behaviors, actions and decisions will take different paths to different outcomes. Finally when all contextual variables which mark the teaching-learning exchange are considered, learning situations, behaviors, actions, and decisions may seem to be too diverse to classify, and too challenging to dissect. But they are also too visible and important to ignore.

\section{References}

Arnold, J., Silvester, J., Patterson, F., Robertson, I., Coopper, C., \& Burnes, B. 2005. Work psychology. Harlow, England: Pearson Education Limited.

Barcelos, A. M. F. 2000. Understanding teachers' and students' language learning beliefs in experience: A Deweyan approach (Unpublished doctoral dissertation). The University of Alabama, Alabama.

Brown, D. H. 2001. Teaching by principles: An interactive approach to language pedagogy. San Francisco, USA: Longman.

Chang, C., \& Shen, M. 2010. The effects of beliefs about language learning and learning strategy use of junior high school EFL learners in remote districts. Research in Higher Education Journal, 8, 1-8. Retrieved from http://www. aabri.com/manuscripts/10462.pdf

Conti, G. J. 2004. Identifying your teaching style. In M. W. Galbraith (Ed.), Adult learning methods: a guide for effective instruction (pp. 75-91). Malabar (FL): Krieger Publishing Company.

Cross, K.P. 1981. Adults as learners. San Francisco: Jossey-Bass.

Dancey, C. P., \& Reidy, J. 2011. Statistics without maths for psychology. Harlow, England: Pearson Education Limited.

Gass, S.M. \& Selinker, L. 2001. Second language acquisition. New Jersey, USA: Lawrence Erlbaum Associates.

Griffiths, C. 2004. Language learning strategies: theory and research. Occasional Paper No. 1, 1-25. Retrieved from http://www.crie.org.nz/research-papers/c griffiths_op1.pdf

Horwitz, E. K. 2013. Becoming a language teacher. Upper Saddle River, USA: Pearson. 
Horwitz, E.K. 1988. The beliefs about language learning of beginning foreign language students. Modern Language Journal, 72(3), 283 - 294.

Hsiao, T., \& Oxford, R. 2002. Comparing theories of language learning strategies: A confirmatory factor analysis. The Modern Language Journal, 86(3), 368-383.

Huddleston, R., \&Pullum, G.K. 2002. The Cambridge grammar of the English language. New York: Cambridge University Press.

Jarvis, P. 1987. Adult learning in the social context. London: Croom Helm.

Jarvis, P. 2003. Adult learning processes. In Jarvis, P. and Griffin, C. (Eds.) Adult and continuing education, Volume IV (pp. 180-198). London and New York: Routledge.

Knox, A. B. 1986. Helping adults learn. San Francisco, USA: Jossey-Bass.

Knowles, M. 1990. The adult learner a neglected species. Houston, USA: Gulf Publishing

Li, F. 2010. Relationship between EFL learners' belief and learning strategy use by English majors in vocational colleges. Journal of Language Teaching and Research, 1(6), 858-866.

McClusky, H. Y. 1963. Course of the adult life span. In W. C. Hallenbeck (Ed.), Psychology of adults (pp. 10-20).Chicago: Adult Education Association of U.S.A.

Mezirow, J. 1991. Transformative dimensions of adult learning. San Francisco, USA: Jossey-Bass.

Nikitina, L. \& Furuoka, F. 2006. Re-examining Horwitz’s beliefs about language learning inventory (BALLI) in the Malaysian context. Electronic journal of foreign language teaching Vol. 3, No. 2, 209-219. Retrieved from http://e-flt.nus.edu.sg/v3n22006/nikitina.pdf

Oxford, R. 1990. Language learning strategies: What every teacher should know. Boston: Heinle and Heinle.

Oxford, R. 2013. Teaching and researching language learning strategies. New York, USA: Routledge.

Rubin, J. 1975. What the "good language learner" can teach us. TESOL Quarterly, 9(1), 41-51.

Saeb, F., \& Zamani, E. 2013. Language learning strategies and beliefs about language learning in high-school students and students attending English institutes: Are they different? English Language Teaching, 6(12), 79-86.

Sternberg, R. J., \& Sternberg, K. 2012. Cognitive psychology. Belmont, USA: Wadsworth.

Weinstein, C. E., \& Mayer, R. E. 1983. The teaching of learning strategies. Innovation Abstracts, 5(32). 3-4. 
Wenden, A. 1991. Learner strategies for learner autonomy. Hemel Hempstead, England: Prentice Hall Europe.

Wenden, A. L. 1998. Metacognitive knowledge and language learning. Applied Linguistics, 19(4), 515-537.

Zmuda, A., Curtis, G., \& Ullman, D. 2015. Learning personalized. San Freancisco, USA: Jossey-Bass. 